\title{
Level of Intercultural Competence of International Students at Kocaeli University*
}

\author{
Gizem Günçavdı*, Soner Polat \\ Faculty of Education, Kocaeli University, Turkey
}

Copyright $\subseteq 2016$ by authors, all rights reserved. Authors agree that this article remains permanently open access under the terms of the Creative Commons Attribution License 4.0 International License

\begin{abstract}
The concept of intercultural competence has gained importance recent years because of some factors, such as globalization and technological improvements. This concept can be defined as an individual's ability to understand other cultures, and to be able to communicate easily with people from those cultures. In order for a person to be interculturally competent, s/he should have intercultural knowledge, attitude, skill and awareness. The aim of this study is to determine Kocaeli University's international students' level of intercultural competence. The population of this study consists of 650 international students in Kocaeli University. The sample of this study includes 230 international students chosen through convenience sampling method. This study is in descriptive survey model. As the data collection tool, "Intercultural Competence" scale developed by Fantini [11] is used. The scale was originally English. Before conducting the scale, researchers adapted it into Turkish. It has been found that international students' level of intercultural competence is high. Also it has been seen that international students' level of intercultural skills, intercultural attitude, intercultural knowledge and intercultural awareness, which are sub-dimensions of intercultural competence, are high. Moreover, it has been found out that the level of intercultural competence differs depending on whether international students got some information about Turkey before coming here, the continents in which international students' home countries are, and international students' level of Turkish language proficiency.
\end{abstract}

Keywords Intercultural Competence, Multicultural University, İnternational Students

\section{Introduction}

Globalization shows its effect on many different areas and education is one of them. It is highly possible that universities are exposed to effects of globalization more than other educational institutions, because universities in Turkey have become institutions where international students come and take part in teaching and learning process thanks to exchange programmes and exams (e.g.: Erasmus Student Exchange Programmes and YÖS-Foreign Student Exam). As a result of this, multi-cultural contexts arise and intercultural competence becomes important in universities. Before defining the concept of multiculturalism, it will be beneficial to explain what the culture is. There are many different definitions for the concept of culture in literature. UNESCO [20] defined the culture as "all physical, spiritual, mental and logical features that defines the characteristic of a society or a social community". Multiculturalism, on the other hand, is that "a society in a certain geographical zone consists of different ethnic, religious, moral, cultural groups and social class due to historical and migration-dependent reasons" [22].

In order for people live in multi-cultural society to live happily and in harmony, intercultural competence is important. While Deardorff [9] defined the concept of intercultural competence as "behaving effectively and according to intercultural knowledge, attitude, skills and reflections"; Repečkienè, Kvedaraite and Jankauskienè [17] defined this concept as "the individual's ability to interact with the people who are members of other group, culture or a community". As can be seen in definitions intercultural competence improves depending on the knowledge about different cultures and attitudes towards them; and also it makes the communication with people from different cultures and adaptation to a new culture easier for the individual.

As Byram [6], Deardorff [8] and Fantini [11] stated, intercultural competence includes skills, attitudes, knowledge, behaviour and comprehension about other cultures, which is important to live in today's globalised world. Thus it is possible to say that having international competence is an important competency in today's world, because the world has become smaller in recent years thanks to internet, social media, easier and cheaper opportunities for travelling from one country to another, and related to this, exchange programmes for students at universities. All of these require being interculturally competent for an individual to survive in such a world. Researchers have paid 
attention to intercultural competence of undergraduate students in European countries ([30]; [25]). In these researches, the common thing researchers found was that international competence was valued by students, and the students saw tolerance and harmony towards other cultures as important skills. In the light of these, the researchers decided to identify the situation at Turkey, and the research has aimed to define the level of intercultural competence of international students at Kocaeli University, a state university in Turkey which gives importance student exchange programme and pay attention to attracting more international students each year by seeing this as a richness.

\subsection{The Aim of the Study}

The main aim of the study is to define the level of intercultural competence of international students at universities in Turkey. Also these sub-problems are aimed to answer:

1. What is the level of intercultural knowledge, intercultural attitude, intercultural skill and intercultural awareness which are sub-dimensions of intercultural competence of international students at Kocaeli University?

2. Does the level of intercultural competence of international students at Kocaeli University show significant differences depending on gender, knowing foreign language(s), being abroad before, gathering information about Turkey before coming, the continents where their home country is stated and their level of Turkish language proficiency?

\section{Intercultural Competence}

The concept of intercultural competence has been paid attention in recent years. Berardo [3] described the intercultural competence as "the capacity of behaving effectively and accordingly by using the intercultural sources". In other words, it is possible to say that intercultural competence means having the necessary skills, knowledge, attitudes and behaviour to know both one's her/his own culture and other cultures, behaving accordingly. Different researchers ([6]; [8]; [11]; [18]; [2]) classified intercultural competence in different ways. According to Bennett [2], intercultural competence is comprised of the dimensions of cognitive, affective and behavioural skills. The cognitive dimension of intercultural competence includes intercultural awareness, general knowledge and specific cultural knowledge. The affective dimension of intercultural competence consists of an individual's curiosity towards other culture, cognitive flexibility, motivation to learn, and being open-minded. The dimension of behavioural skill of intercultural competence includes the ability of communicating with people from different cultures, listening to them, problem-solving, empathy, and gathering information.
Deardorff [8] developed the "pyramid model" of intercultural competence. This model includes four steps depending on five dimensions. In order for an individual to gain intercultural competence, $\mathrm{s} / \mathrm{he}$ has to have the qualifications of these four steps. The first dimension is named as "requisite attitudes". This dimension contains the "respect" for other cultures, "openness" to intercultural learning and other cultures, "curiosity" and "exploring". Deardorff [8] values this step as the beginning for gaining intercultural competence. The second dimension is named as "knowledge and comprehension". The individual's awareness of her/his own culture and others' culture, awareness of the effect of social factor on the use of language and skills of reading the culture, having the information about the culture and understanding are included in this dimension. Another dimension which is interrelated with this dimension is "skills". This dimension is also is the second step of Deardorff's pyramid model of intercultural competence, together with the dimension of "knowledge and comprehension". The "skills" dimension includes listening to people from other cultures, observing other cultures, interpreting them, evaluating and relating the cultures. The last two dimensions and two steps are "desired internal outcome" and "desired external outcome". The "desired internal outcome" dimension consists of adapting to new cultural environments, flexibility about choosing and using the appropriate communication styles, and empathy. On the other hand, the "desired external outcome" dimension includes the individual's having the skills of communication and behaving accordingly and effectively in order to achieve intercultural purposes depending on her/his intercultural knowledge, skills and attitudes. Deardorff [8] emphasized that the process of intercultural competence can also be circular rather than being linear.

Another model about intercultural competence was developed by Ruben. Ruben took intercultural competence in seven dimensions [18]. These dimensions are "respect" (respecting other individuals and approaching them in a positive manner), "attitude toward interaction" (the individual's ability to respond others without judging them), "getting used to the knowledge" (the individual's ability to understand that the people around them may have different points of view about world), "empathy", "mission-role behaviours" (the individual's ability to be flexible about starting the role and bring them together), "interaction management" (the individual's ability to take part in quarrels and starting and finishing the interactions which occurs depending on others needs and desires) and "tolerating to uncertainty" (the individual's ability to react to new and uncertain situations with the minimum uneasiness".

Another approach about intercultural competence was put forward by Byram [6]. According to this approach, intercultural competence includes five dimension which are "attitude", "knowledge", "interpreting and relating skills" (interpreting an event belonging to another culture and explaining this event by relating it with the situations of her/his culture), "exploring and interacting skills" (gaining 
new information about a culture and the cultural implementations) and "critical cultural awareness" (the individual's ability to evaluate her/his own culture and points of view of other culture in terms of implementations and products in a critical way).

Another classification about intercultural competence was made by Fantini [11]. Fantini [11] divided intercultural competence into four dimensions which are intercultural knowledge, intercultural attitude, intercultural skill and intercultural awareness.

Intercultural Knowledge: This dimension is also considered as the conceptual aspect of intercultural competence [10]. Intercultural knowledge is taken into consideration as an individual's skills to gain knowledge about products of the people of his/her own culture or another culture with which s/he interacts, and the skill to have relevant information which would help the individual to interact with people from the other culture personally [6]. While Deardorff [8] described intercultural knowledge as the competence to have the information about a specific culture, Fantini [10] defined it as knowing the hosting culture.

Intercultural Attitude: This dimension includes being open and respect to, interest in and curiosity about different cultures [8]. In addition to these, being risk-oriented, empathic, open-minded and respecting differences are among the other intercultural attitudes ([14]; [15]). Byram [6] also emphasized that intercultural attitude is a concept which is affected by curiosity, social class, gender and race.

Intercultural Skill: Intercultural skill is considered as the ability to listen to people from other cultures, observe other cultures, interpret, analyse, evaluate and relate them [8]. Besides, skills to learn a second or third language, skills to stand up to the difficulties faced during the process of learning a second or third language, skills to interrelate languages with each other, listening skills, information gathering skills and problem solving skills are among the intercultural skills ([14]; [15]). Fantini [10] explained that this dimension can also be named as "intercultural behaviour" and this dimension is affected by other dimensions.

Intercultural Awareness: Byram [6] defined intercultural awareness as an individual's ability to see the similarities and differences between her/his own culture and the other culture with a criticising point of view. Intercultural awareness is also seen as an individual's conscious of improving her/his attitudes, knowledge and skills while learning her/his own culture and other cultures.

\section{Method}

\subsection{Research Design}

This study is in the model of descriptive survey that aims to define the level of intercultural competence of international students at Kocaeli University.

\subsection{Population and Sample}

The population of this study included 650 international students at Kocaeli University. The sample of this study was chosen through convenience sampling and included 230 international students. The $64,17 \%$ of the sample was male students, $34,83 \%$ of the sample was female students. The $28,4 \%$ of the sample (58 students) was from Europe (Bulgaria, Montenegro, Greece, Macedonia, Kosovo, Russia, Germany, France and Moldova), the $65,7 \%$ of the sample (134 students) was from Asia (Turkmenistan, Azerbaijan, Kazakhstan, Kirghizstan, Tajikistan, Uzbekistan, Mongolia, Indonesia, Georgia, Iran, Syria, China, Afghanistan and Pakistan), and 5,9\% of the sample was from Africa (Djibouti, Niger, Uganda, Tunisia, Mauretania and Zambia). Also, 24 of the students from Europe were from Balkan countries, and 110 of the students from Asia were from Turkic countries. When it comes to Turkish language proficiency of international students, 69 of them (33,5\%) knew Turkish at the level of $\mathrm{C} 2,58$ of them $(28,2 \%)$ knew Turkish at the level of $\mathrm{C} 1,23$ of them $(11,2 \%)$ knew Turkish at the level of B2, 18 of them $(8,7 \%)$ knew Turkish at the level of B1, 18 of them $(8,7 \%)$ knew Turkish at the level of A2, and 20 of them $(9,7 \%)$ knew Turkish at the level of A1.

\subsection{Data Collection Tool}

The data collection tool of this study was "Intercultural Competence Scale" developed by Fantini [11]. This scale consists of 53 items and they are formed as 5-likert type. There are four sub-dimensions in the scale which are "knowledge", "attitude", "skills" and "awareness". The scale items were prepared both in Turkish and in English in case international students did not know Turkish adequately. While preparing Turkish form of the scale, five post-graduate students at educational administration who graduated from department of English Language Teaching translated the items from English to Turkish. After that, the scale's Turkish form was conducted to 250 senior students who were the students of faculty of education and they weren't included in the sample. Because of the fact that the scale consisted of 53 items and it was suggested that the number of participants had better be 5 times more than the number of items [21], this number was thought to be sufficient. Those students expressed their ideas about which items were difficult to understand in Turkish, or may be difficult for international students to understand. In the lights of their recommendations and researchers' evaluations about them, the Turkish form of the scale was prepared. Then, both English and Turkish forms were conducted to international, post-graduate students who were not included in the sample; and necessary changes were made to items which are hard to understand before conducting the scale to sample.

After data were collected, explanatory factor analysis were conducted to find out whether the items measured the sub-dimension they belonged to or not. Because it is accepted as good if the factor load of the item is over 0.450 
for factor analysis [5], the researcher decided to keep the items which had factor load over 0.450 . As a result of this, items 1., 2., 12., 15., 18., 27., 29., 46., 49., and 52. were excluded, and 43 items were analyzed. KMO factor load was found as 0.92, which is over 0.70. Also results of Bartlett's test of sphericity was significant $(\mathrm{df}=903, \mathrm{p}<0.001)$. These results showed the suitability of the factor analysis of this scale. After factor analysis was performed, it was seen that the scale includes four dimensions. The first dimension explained $59,055 \%$ of total variance (Eigenvalue $=25,394$ ), the second dimension explained $5,860 \%$ of total variance (Eigenvalue $=2,520$ ), the third dimension explained 3,634\% of total variance (Eigenvalue $=1,563$ ) and the fourth dimension explained $2,893 \%$ of total variance (Eigenvalue $=1,244$ ). The mutual variance of the four factors changed between $59 \%$ and $71 \%$. The factor loads of the items differed between 0,471 and 0,828 . The factors were named after sub-dimensions of intercultural competence respectively; which are "intercultural awareness", "intercultural attitude", "intercultural knowledge" and "intercultural skills".

The Cronbach Alpha reliability values of Intercultural Competence Scale and its sub-dimensions were given in Table 1. Cronbach Alpha reliability value of the Intercultural Competence Scale was found as 0.98 . This results shows that this scale is highly reliable. The reliability values of the sub-dimensions changed between 0.90 and 0.96 . These results also show that the sub-dimensions of the scale are highly reliable, as well.

Table 1. The Values of Intercultural competence Scale and Its Sub-dimensions

\begin{tabular}{|c|c|c|c|c|}
\hline $\begin{array}{l}\text { The } \\
\text { Sub-Dimensions } \\
\text { of Intercultural } \\
\text { Competence } \\
\text { Scale }\end{array}$ & $\begin{array}{l}\text { The } \\
\text { Number } \\
\text { of Items }\end{array}$ & Items & $\begin{array}{l}\text { Factor } \\
\text { Loads }\end{array}$ & $\begin{array}{c}\text { Cronbach- } \\
\text { Alpha } \\
\text { Reliability } \\
\text { Value }\end{array}$ \\
\hline $\begin{array}{l}\text { Intercultural } \\
\text { Awareness }\end{array}$ & 17 & $\begin{array}{c}3,10,11, \\
20,21,25,26, \\
35,36,37,38, \\
44,47,48,50, \\
51,53\end{array}$ & $0.551-0.791$ & 0.96 \\
\hline $\begin{array}{l}\text { Intercultural } \\
\text { Attitude }\end{array}$ & 13 & $\begin{array}{c}5,6 \\
8,13,14,16 \\
24,28,31,32 \\
33,41,45\end{array}$ & $0.595-0.828$ & 0.96 \\
\hline $\begin{array}{l}\text { Intercultural } \\
\text { Knowledge }\end{array}$ & 8 & $\begin{array}{c}4,7,9,23,30 \\
34,42,43\end{array}$ & $0.550-0.770$ & 0.94 \\
\hline $\begin{array}{l}\text { Intercultural } \\
\text { Skills }\end{array}$ & 5 & $\begin{array}{c}17,19,22,39 \\
40\end{array}$ & $0.471-0.616$ & 0.90 \\
\hline $\begin{array}{l}\text { Intercultural } \\
\text { Competence }\end{array}$ & 43 & & $0.471-0.828$ & 0.98 \\
\hline
\end{tabular}

After explanatory factor analysis, confirmatory factor analysis was performed on 43 items and the four factors. Firstly the suitability of the model was tested with confirmatory factor analysis. For the suitability of the model, the values of $\chi^{2} / \mathrm{df}$ (Chi-Square/Degrees of Freedom), CFI (Comparative Fit Index), NNFI (Non-Normed Fit Index), RMR (Root Mean Square Residual), RMSEA (Root Mean Square Error of Approximation) were taken as criteria. The results were $\chi^{2} / \mathrm{df}=4.44(\mathrm{p}<.001), \mathrm{CFI}=0.95, \mathrm{NNFI}=0.95$, $\mathrm{RMR}=0.061, \mathrm{RMSEA}=0.12$. When these values were analyzed in detail, it is seen that the value of $\chi^{2} / \mathrm{df}$ is under 5 , and it is seen as acceptable [19]. Also CFI and NNFI values which are more than 0.90 is seen as perfect harmony [12]. The RMR value under 0.08 is considered as good harmony [4]. However, in this study RMSEA value was 0.12 . If this value equals to 0.10 or if it is less than 0.10 , it is seen as weak harmony [13], which is the situation in this study.

After the values mentioned below, the level of significance of $t$ values was analyzed, because insignificant $t$ values are excluded in confirmatory factor analysis, and error variances are examined before the items with insignificant $t$ values are excluded [7]. Error variances of all variables were between 0.20 and 0.57 . Also $t$ values were more than 2.56, which shows that they are significant at the level of 0.01 .

\subsection{Data Collection and Analysis}

Researchers asked the 230 international students at Kocaeli University to fill in the questionnaire, which was formed on an online website, by sending e-mails to them that included the link of that website. All the 230 international students filled in the form online, but 22 students were excluded from data analysis because of the fact that they marked the same answers systematically for all items. As a result of this, the analysis was conducted to data of 208 international students.

In order to interpret the level of intercultural competence, arithmetic mean was taken as criteria. While analyzing arithmetic means, ranges were evaluated as 1.00-1.79 "very low", 1.80-2.59 "low", 2.60-3.39 "average", 3.40-4.19 "high", and 4.20-5.00 "very high". In order to analyze whether the level of intercultural competence of international students showed significant difference depending on gender, knowing foreign language(s) and being abroad before, independent samples $t$ test was used. To analyze whether the level of intercultural competence of international students showed significant difference depending on gathering information about Turkey before coming, and the continents where their home country is stated, Kruskal Wallis and Mann Whitney U tests were used. Lastly, to analyze whether the level of intercultural competence of international students showed significant difference depending on their level of Turkish, one-way ANOVA was used.

\section{Findings}

The values related to level of intercultural competence and the level of competence related to its sub-dimensions, which are intercultural knowledge, intercultural attitude, intercultural skills and intercultural awareness, of international students at Kocaeli University are shown at Table 2. As it can be seen at this table, international students' level of intercultural competence is high $(\bar{X}=3.91)$. 
International students' level of intercultural skills ( $\bar{X}=4.00)$, intercultural attitude $(\bar{X}=3.97)$, intercultural knowledge $(\bar{X}=3.88)$ and intercultural awareness $(\bar{X}=3.79)$ are high, as well (Table 2).

Table 2. Arithmetic Mean and Standard Deviation Values of Intercultural Competence and Its Sub-Dimensions

\begin{tabular}{cccc}
\hline Sub-Dimensions & $\mathrm{N}$ & $\bar{X}$ & $\mathrm{Ss}$ \\
\hline Intercultural Skills & 208 & 4.00 & 0.82 \\
Intercultural Attitude & 208 & 3.97 & 0.81 \\
Intercultural Knowledge & 208 & 3.88 & 0.86 \\
Intercultural Awareness & 208 & 3.79 & 0.87 \\
Intercultural & 208 & 3.91 & 0.77 \\
Competence & &
\end{tabular}

The $t$ test was used to analyze whether the level of intercultural competence of international students showed significant difference depending on gender, and gathering information about Turkey before coming. It was found that international students' level of intercultural competence did not show significant difference according to gender $(t=-1,341, p=0.181>0.05)$. In contrast to this, their level of intercultural competence showed significant difference depending on gathering information about Turkey before coming $(\mathrm{t}=2.242, \mathrm{p}=0.027<0.05)$. The results are shown in Table 3 .

Table 3. The Results of Independent Samples $t$ Test Related to International Students' Gathering Information about Turkey before Coming

\begin{tabular}{cccccc}
\hline & & $\mathrm{N}$ & $\bar{X}$ & $\mathrm{t}$ & $\mathrm{p}$ \\
\hline Intercultural & Yes & 164 & 3.83 & 1.408 & 0.163 \\
Awareness & No & 44 & 3.65 & & \\
& & & & & \\
Intercultural & Yes & 164 & 4.04 & 1.361 & 0.175 \\
Skills & No & 44 & 3.85 & & \\
& & & & & \\
Intercultural & Yes & 164 & 3.94 & 2.227 & 0.027 \\
Knowledge & No & 44 & 3.62 & & \\
Intercultural & Yes & 164 & 4.03 & 2.098 & 0.037 \\
Attitude & No & 44 & 3.74 & & \\
Intercultural & Yes & 164 & 3.96 & & \\
Competence & No & 44 & 3.71 & 2.242 & 0.027 \\
\hline
\end{tabular}

The results of $t$ test shows that the level of intercultural competence of international students who gathered information about Turkey before coming $(\bar{X}=3.96)$ is higher than those who $\operatorname{did} \operatorname{not}(\bar{X}=3.71)$.

To test whether there is a relationship between international students' gathering information about Turkey before coming and sub-dimensions of intercultural competence, $t$ test was used. The results showed that intercultural skill $(\mathrm{t}=1.361, \mathrm{p}=0.175>0.05)$ and intercultural awareness $(\mathrm{t}=1.408, \mathrm{p}=0.163>0.05)$ did not show significant difference depending on gathering information about Turkey before coming. However; intercultural knowledge $(\mathrm{t}=2.227$, $\mathrm{p}=0.027<0.05)$ and intercultural attitude $(\mathrm{t}=2.098$, $\mathrm{p}=0.037<0.05$ ) showed significant difference depending on this variable. When the sub-dimension of intercultural knowledge is considered, it was seen that international students who gathered information about Turkey before coming had higher intercultural knowledge $(\bar{X}=3.94)$ than those who did not $(\bar{X}=3.62)$. For the intercultural attitude, similar results were found. International students who gathered information about Turkey before coming had higher intercultural attitude $(\bar{X}=4.03)$ than those who did $\operatorname{not}(\bar{X}=3.71)$.

Among international students, the highest level of intercultural competence belonged to the European students $(\bar{X}=4.22)$. Asian students $(\bar{X}=3.83)$ and African students $(\bar{X}=3.43)$ followed them respectively. In order to analyze whether international students' level of intercultural competence showed significant difference depending on the continents they came, Kruskal-Wallis test was used (Table 4). With the aim of understanding between which continents there was significant difference, Mann-Whitney U test was implemented. According to the results of Kruskal-Wallis test, there was significant difference among international students' level of intercultural competence depending on the continent they came from $(p=0.00<0.05)$. In addition to these results, results of Mann-Whitney $U$ test showed that there was significant difference between Asian and European students' level of intercultural competence $(\mathrm{p}=0.00<0.05)$, and European and African students' level of intercultural competence $(p=0.018<0.05)$. However, there was not significant difference between Asian and African students' level of intercultural competence $(\mathrm{p}=0.425>0.05)$.

Table 4. Results of Kruskal-Wallis Tests that Shows International Students' Level of Intercultural Competence Depending on the Continents They Came From

\begin{tabular}{|c|c|c|c|c|c|c|}
\hline $\begin{array}{c}\text { The continent } \\
\text { where international } \\
\text { students' countries } \\
\text { were located }\end{array}$ & $\mathrm{N}$ & $\%$ & $\bar{X}$ & ss & $\mathrm{Sd}$ & $\mathrm{p}$ \\
\hline Africa & 12 & 5.9 & 3.43 & 1.04 & 2 & 0.00 \\
\hline Asia & 134 & 65.7 & 3.83 & 0.76 & & \\
\hline Europe & 58 & 28.4 & 4.22 & 0.62 & & \\
\hline Total & 204 & & & & & \\
\hline
\end{tabular}

It was seen that the highest level of intercultural competence based on Turkish language proficiency belonged to the international students with $\mathrm{C} 2$ level of language proficiency $(\bar{X}=4.35)$. This group was followed by international students with $\mathrm{C} 1$ level of language proficiency $(\bar{X}=3.91)$, international students with B2 level of language proficiency $(\bar{X}=3.79)$, international students with B1 level of language proficiency ( $\bar{X}=3.79$ ), international students with A2 level of language proficiency ( $\bar{X}=3.53$ ) and international students with A1 level of language proficiency $(\bar{X}=3.18)$ respectively. As it can be seen from these results, while international students' level of Turkish language proficiency lessened, their level of intercultural competence decreased as well (Table 5). 
Table 5. The Results of Dunnett C Test about International Students' Turkish Language Proficiency

\begin{tabular}{ccccccc}
\hline $\begin{array}{c}\text { Language } \\
\text { Proficiency } \\
\text { Level }\end{array}$ & $\mathrm{N}$ & $\bar{X}$ & $\mathrm{~S}$ & $\mathrm{~F}$ & $\mathrm{p}$ & Dunnett C \\
\hline A1 & 20 & 3.18 & 0.97 & 11.044 & 0.00 & $\begin{array}{c}\mathrm{A} 1 \text { and A2, B1, } \\
\mathrm{B} 2, \mathrm{C} 1, \mathrm{C} 2\end{array}$ \\
$\mathrm{~A} 2$ & 18 & 3.53 & 1.18 & & $\mathrm{~A} 2$ and C1, C2 \\
B1 & 18 & 3.79 & 0.28 & & $\mathrm{C} 2$ and B1, B2, \\
B2 & 23 & 3.79 & 0.50 & & $\mathrm{C} 1$ \\
$\mathrm{C} 1$ & 58 & 3.91 & 0.59 & & \\
$\mathrm{C} 2$ & 69 & 4.35 & 0.64 & & \\
\hline
\end{tabular}

To test whether international students' level of intercultural competence showed significant difference depending on their Turkish language proficiency, One Way ANOVA was performed (Table 5). The results of ANOVA test showed that there was significant difference among the levels of language proficiency $(\mathrm{F}=11.044, \mathrm{p}<0.01)$.

In addition to the findings above, it was also seen that there was significant difference among the international students with high levels of language proficiency and international students with low levels of language proficiency in terms of intercultural competence.

\section{Results and Discussion}

Within this study, it was found that level of intercultural competence and level of its sub-dimensions intercultural knowledge, intercultural attitude, intercultural skill and intercultural awareness of international students at Kocaeli University were high. It was seen that most of the international students came from countries that had similar cultures to Turkey's. Thus, it is possible to think that this fact was effective on students' high levels of intercultural competence. Besides, international students told that they attended some orientation programmes about Turkish culture both before coming to Kocaeli University and after having enrolled. Another finding of this study is that international students' level of intercultural competence showed significant difference depending on whether they gathered information about Turkey before coming or not. Among international students, the ones who gathered information about Turkey before coming had higher level of intercultural competence than those who did not. This condition caused significant difference on the dimensions of intercultural knowledge and attitude. From this perspective, it is possible to say that gathering information about a different culture has positive impact on intercultural knowledge and attitude. Fantini [11] made a study about volunteers who helped people that are in need in terms of health and educational issues, and in his study he analyzed the impact of volunteers' attending orientation programs about the countries they went on their level of intercultural competence. Results of Fantini's [11] study showed that there was considerable difference between volunteers' level of intercultural competence when they went to that country at first, and their level of intercultural competence when their mission finished on that country. Also volunteers' level of intercultural competence increased after having attended orientation programmes [11]. According to these results it can be suggested that if orientation programmes are prepared for international students about host country, this will increase their level of intercultural competence.

The highest level of intercultural competence belonged to European students, and Asian and African students followed them respectively. It is possible to say that European countries and Balkan countries which are located in that continent have a multicultural structure which helps international students develop intercultural competence. Also it was found that the level of intercultural competence of international students showed significant difference according to the countries they came from. It is thought that international students' chance to face with different cultures has a kind of impact on this situation. Another reason for this difference is believed to be international students' familiarity with Turkish culture and their Turkish language proficiency, because most of international students from Europe and Asia were from countries which are Turkic or relative societies. However, international students from African countries were observed as they did not know Turkish culture or Turkish language adequately.

Penbek, Yurdakul and Cerit [16] made a study about students of Dokuz Eylul Univeristy and Izmir Economy University, and this study results showed that there was positive correlation between students' level of intercultural competence and their level of interaction with different cultures. This study's results are similar to that study's findings.

Another finding of this study is that international students' level of intercultural competence increased when their level of Turkish language proficiency increased. Moreover, there was a significant difference among the levels of intercultural competence of international students with high Turkish language proficiency and levels of intercultural competence of international students with low Turkish language proficiency. As it is known, language is considered as the most important aspect of the culture of the society where it is spoken [1]. So, one of the factors that affects an individual's level of intercultural competence is his/her language proficiency. If international students know host country's language and use it effectively, this will increase their level of intercultural competence. Because of this, some opportunities where international students can use host country's language more frequently should be provided.

As any other study, this one has some limitations as well. This study was conducted only to international students at Kocaeli University. Other researchers can make other studies where contrastive studies at universities both in Turkey and in other countries around the world. 


\section{Note}

*The abstract of this paper was presented at 2nd International Conference on Lifelong Learning and Leadership for All (ICLEL-16), in Liepaja on July, 21-23, 2016.

\section{REFERENCES}

[1] Akarsu, B. (1998). Language- Culture Connection in Wilhelm Von Humboldt. Istanbul: Ink1lap Publishing

[2] Bennett, J. (2011). Developing Intercultural Competence for International Education Faculty and Staff. Paper presented in AIEA Conference, San Francisco/ABD.

[3] Berardo, K. (2005). Intercultural competence: A synthesis and discussion of current research and theories. University of Luton Business School.

[4] Brown, T.A. (2006). Confirmatory factor analysis for applied research. (First edition). New York: Guilford Publications, Inc.

[5] Büyüköztürk, Ş. (2005). Multi-varied Statistics. Handbook for data analysis in social sciences (pp.123-143). Ankara: Pegem Akademi.

[6] Byram, M. (2000). Assessing intercultural competence in language teaching. Sprogforum, 18 (6), 8-13.

[7] Çokluk, Ö., Şekercioğlu,G.,\& Büyüköztürk, Ş. (2012). Structural equation model. Multi-varied statistics for the social sciences: SPSS and LISREL Applications (pp.251-405). Ankara: Pegem Akademi.

[8] Deardorff, D.K. (2006). Identification and assessment of intercultural competence as a student outcome of internationalization, Journal of Studies in International Education, 10(3), 241-266.

[9] Deardorff, D.K. (2010). Intercultural Competence in the Classroom. Paper presented in EAIE Conference, Nantes/ Fransa.

[10] Fantini, A. (2000). A central concern: Developing intercultural competence. About Our Institution, 25-42.

[11] Fantini, A. (2007). Exploring and Assessing Intercultural Competence. Washington University, USA.

[12] Hu, L.,\& Bentler, P.M. (1999). Cutoff criteria for fit indexes in covariance structure analysis: Conventional criteria versus new alternatives.Structural Equation Modeling, 6,1-55.

[13] Kelloway, K.E. (1989). Using Lisrel for structural equation modeling: A researcher's guide. London:Sage.

[14] Martin, J.N. \&Nakayama, T.K. (2004). Intercultural communication in context. New York: McGraw Hill.

[15] Odgers, T. (2009). Leading in international and intercultural education. Presentation presented in AB:Centre for Excellence in Intercultural Education, Norquest College, Edmonton.

[16] Penbek, Ş., Yurdakul, D. ve Cerit, A.G. (2009). Intercultural Communication Competence: A Study About The Intercultural Sensitivity Of University Students Based On Their Education And İnternational Experiences. EMOIS 2009 'da Sunulan Bildiri, İzmir/Türkiye.

[17] Repečkienè, A., Kvedaraitè, N.,\& Jankauskienė, V. (2011). Intercultural competence as precondition for cultural diversity management. Economics and management, 16, 882-891.

[18] Sinicrope,C., Norris, J.,\& Watanabe, Y. (2007). Understanding and assessing intercultural competence: A summary of theory, research, and practice (Technical report for the foreign language program evaluation project). Second language studies, 26(1), 1-58.

[19] Sümer, N. (2000). Yapısal eşitlik modelleri. Türk Psikoloji Yazıları, 3(6),49-74.

[20] UNESCO (1982). Mexico City Declaration on Cultural Policies.

http://portal.unesco.org/culture/en/files/12762/11295421661 mexico_en.pdf/mexico_en.pdf [29.05.2013]

[21] Tavşancıl, E. (2002). Tutumların ölçülmesi ve spss ile veri analizi. Ankara: Nobel Yayıncılık.

[22] Yazıcı,S., Başol,G. \& Toprak,G. (2009). Öğretmenlerin çok kültürlü eğitim tutumları: bir güvenirlik ve geçerlik çalışması. Hacettepe Üniversitesi Eğitim Fakültesi Dergisi (H. U. Journal of Education) ,37, 229-242.

[23] İncik EY, \& Yelken TY (2011). Elementary Teacher Candidates' Levels of Innovation. Example of Mersin University. The First International Congress on Curriculum and Instruction (05-08 Ekim). Paper presented, Eskişehir, Türkiye.

[24] Karasar, N. (2005).Bilimsel Araştırma Yöntemi. Ankara: Nobel Yayınları.

[25] Keller, T.M. \& Hodge, A. (2016). Ireland in pictures: Intercultural competence among undergraduate college students. Paper presented in The Qualitative Report Conference, 2016.

[26] Kert, S.B. \& Tekdal, M. (2012). Comparison of individual innovativeness perception of students attending different education faculties. Gaziantep University Journal of Social Sciences, 11(4)-1150-1161.

[27] Kılıçer, K. \& Odabaşı, F.H. (2010). Bireysel yenilikçilik ölçeği (BYÖ): türkçeye uyarlama, geçerlik ve güvenirlik çalışması. Hacettepe Üniversitesi eğitim Fakültesi Dergisi, 38: 150-164.

[28] Kılıçer, K. (2011). Bilgisayar ve öğretim teknolojileri eğitimi öğretmen adaylarinin bireysel yenilikçilik profilleri. Yayımlanmamış Doktora Tezi, Anadolu Üniversitesi, Eskişehir.

[29] Kondakçı,Y., Zayim, M. \& Çalışkan, Ö.(2013) Değişime Hazır Olma Ölçeği'nin Geçerlilik ve Güvenilirlik Çalışması. Elementary Education Online, 12(1), 23 - 35.

[30] Odağ, Ö., Wallin, H.R., \& Kedzior, K.K. (2015). Definition of intercultural competence according to undergraduate students at an international university in Germany. Journal of Studies in International Education, 1-22.

[31] Uzkurt, C. (2008). Pazarlamada değer yaratma aracı olarak yenilik yönetimi ve yenilikçi örgüt kültürü.İstanbul: Beta Basım A.Ş.

[32] Xu, X. (2009), Communıcatıng innovation: an appreciative inquiry investigation into innovation in china. Unpublished Master Thesis The University Of Waikato, New Zealand

[33] Zayim, M. (2010), Investıgatıng the relationship between primary and secondary level public school teachers' readiness for change and perceived organizational trust. Unpublished Master Thesis Middle East Technical University, Turkey. 